Tinbergen Institute Discussion Paper

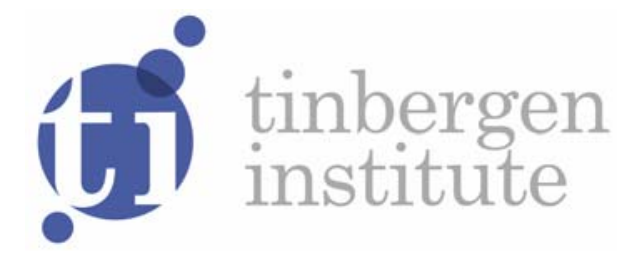

\title{
Employers Opting Out of Public Disability Insurance: Selection or Incentive Effects?
}

\author{
Wolter H.J. Hassink ${ }^{1}$ \\ Pierre Koning 2 \\ Wim Zwinkels3
}

' Utrecht University School of Economics, the Netherlands;

2 Faculty of Economics and Business Administration, VU University Amsterdam, and Tinbergen Institute, the Netherlands;

${ }^{3}$ Epsilon Research, the Netherlands. 
Tinbergen Institute is the graduate school and research institute in economics of Erasmus University Rotterdam, the University of Amsterdam and VU University Amsterdam.

More TI discussion papers can be downloaded at http://www.tinbergen.nl

Tinbergen Institute has two locations:

Tinbergen Institute Amsterdam

Gustav Mahlerplein 117

1082 MS Amsterdam

The Netherlands

Tel.: +31(0)205251600

Tinbergen Institute Rotterdam

Burg. Oudlaan 50

3062 PA Rotterdam

The Netherlands

Tel.: +31(0)10 4088900

Fax: $+31(0) 104089031$

Duisenberg school of finance is a collaboration of the Dutch financial sector and universities, with the ambition to support innovative research and offer top quality academic education in core areas of finance.

DSF research papers can be downloaded at: http://www.dsf.nl/

Duisenberg school of finance

Gustav Mahlerplein 117

1082 MS Amsterdam

The Netherlands

Tel.: +31(0)20 5258579 


\title{
Employers Opting Out of Public Disability Insurance: Selection or Incentive Effects?
}

\author{
Wolter H.J. Hassink \\ UTRECHT UNIVERSITY SCHOOL OF ECONOMICS AND IZA \\ KRIEKENPITPLEIN 21-22 \\ NL 3584 EC UTRECHT \\ THE NETHERLANDS \\ P.O. BOX 80125 \\ Email: w.h.j.hassink@uu.nl
}

Pierre Koning

VU UNIVERSITY AMSTERDAM, TINBERGEN INSTITUTE AND IZA DEPARTMENT OF ECONOMICS

DE BOELELAAN 1105

NL $1081 \mathrm{HV}$ AMSTERDAM

THE NETHERLANDS

P.O. BOX 80510

Email: p.w.c.koning@vu.nl

+3170-3334009

Wim Zwinkels

EPSILON RESEARCH

ROODENBURGERSTRAAT 22

NL 2313 HK LEIDEN

THE NETHERLANDS

Email: wim.zwinkels@epsilon-research.nl

July 2015 


\title{
Employers Opting Out of Public Disability Insurance: Selection or Incentive Effects? ${ }^{1}$
}

\begin{abstract}
This paper analyzes selection and incentive effects of opting out from public to private insurance on employer Disability Insurance (DI) inflow rates. We use administrative information on DI benefit costs and opting-out decisions of a balanced panel of about 140,000 employers that are observed between 2007 and 2011. We argue that the optingout decision of employers was driven by current DI enrolment and anticipation effects that resulted from short-term expectations on DI costs. In particular, employers opted out when this was most rewarding for them in reducing DI premium rates. When controlling for these effects, our main finding is that there are no incentive effects due to opting out. Thus, publicly and privately insured employers show similar DI inflow rates.
\end{abstract}

Key words: Public versus private insurance, Disability insurance, Opting out, Longitudinal analyses.

JEL codes: Panel data models (C23); Health Insurance, public and private (I13).

\footnotetext{
${ }^{1}$ Workshop participants at the Danish National Centre of Social Research in Copenhagen (4 November 2014), the meeting of the Centre for Research in Active Labour Market Policy Effects in Borkop (17-19 December 2014), OECD (12 March 2015), and the CPB Netherlands Bureau of Economic Policy Analysis (21May 2015) are grafefully acknowledged for comments to the paper. In addition, we thank UWV for providing us access to the data.
} 


\section{INTRODUCTION}

At present, many countries are facing a rise in the rate of public Disability Insurance (DI) enrolment (Autor and Duggan, 2006; Burkhauser et al., 2014). As a result, the call for privatization of DI schemes - with stronger employer incentives to reduce DI enrolment - has become louder in recent years (OECD, 2010). ${ }^{2}$ For the strongest form of experience rating with the largest incentives, firms would be 'perfectly experience rated'. In other words, it would effectively lead to a privatized system of DI, in which individual firms fully bear the cost of the disability enrolment of their workers. ${ }^{3}$

The implementation of employer incentives by means of a privatized system of DI poses the challenge of providing a continued insurance coverage of individual workers thus avoiding classic adverse selection problems that are common in private social insurance (Cohen and Spiegelman, 2010). As an alternative, one may therefore consider the use of a mixed insurance system that combines the public and private provision of DI. In such a setting, employers can opt out from public DI and they have an insurance contract with a private provider of DI instead. Opting out thus implies the partial privatization of DI, while ensuring insurance coverage for all workers.

Unfortunately, knowledge of the functioning of mixed systems of DI is limited. For Workers' Compensation (WC), Texas is the only state in the US where a substantial

\footnotetext{
2 The use of experience rating is most well known for the systems of Workers' Compensation in the US and Canada. To our knowledge, in Europe DI experience rating is used only in DI schemes in the Netherlands and Finland (Koning, 2009; Kyyrä and Tuomala, 2013).

${ }^{3}$ It has been argued that such a system of self-insurance can be inferred from experience rating effects with employers bearing all DI benefits costs. For instance, Seabury et al. (2012) use self-insurance as a proxy for experience rating.
} 
fraction of employers is both self-insured and registered as a 'non-subscriber' ${ }^{4}$ Empirical analyses of this system have examined the motives for self-insurance and the incentives non-subscribers have in underreporting injury rates - see Morantz (2010) and Butler (1996), respectively. ${ }^{5}$ In Europe, the Netherlands has been the first (and so far only) country that provides employers the opportunity to opt out from the public DI system to one of various private insurers. Thus, opting out implies a switch from public insurance which is pay-as-you-go funded - to a private insurer - which is capital funded. Importantly, it means that employers must warrant the continued payment of the DI costs of current disabled employees after they have switched from public to private DI. With various private providers of DI, there may be competition on the insurance premium, the insurance coverage, and on the provision of reintegration activities to prevent inflow and effectuate the outflow of disability.

The major question that we will investigate in this paper is whether the mixed system of a private and public DI in the Netherlands leads to the classic mechanisms of sorting and incentives that are common in insurance markets. ${ }^{6}$ If so, one would expect firms with a limited use of public DI to switch to private insurers where they can have a

\footnotetext{
${ }^{4}$ In 2010, about $30 \%$ of the employers in Texas was self insured (New Street Group, 2012).

${ }^{5}$ Morantz (2010) surveys 54 large employers that opted out in the state of Texas. She argues that the vast majority of them (98\%) judged the switch as a success that lead to substantial cost savings. Butler (1996) finds that differences in reported lost work days of subscribers and non-subscribers are due to moral hazard in reporting: conditional on sector fatality rates, non-subscribers reported slightly higher injury rates, shorter lost work day durations, and fewer sprains and strains than was done by subscribers.

${ }^{6}$ See Cohen and Spiegelman (2010) and Dionne et al. (2012) for recent surveys of adverse selection and incentive effects in insurances. With most of this literature focusing on automobile insurance, life insurance, and health insurance, we claim that our analysis is the first to study selection in the context of disability insurance.
} 
lower insurance premium. In the Netherlands, this way of selection may have occurred if firms and private insurers anticipated future DI claims. Furthermore, incentive effects may occur if private insurers - which have a stronger interest in claims reduction than the public insurer - increased their preventative and reintegration activities.

We use administrative annual firm-level data for the Netherlands from 2007 to 2011. In this period, the share of employers with private disability insurance increased from $30 \%$ to $37 \%$ - with almost all switches taking place from public insurance to private insurance (and not the reverse). Our empirical analysis specifically considers the use of DI (the rate of DI inflow) of individual firms. In particular, we examine the patterns of the DI inflow for employers that opted out from public to private DI, so as to provide empirical evidence on the relative effectiveness of public insurance versus private insurance.

Importantly, the premiums in the public system of DI are experience rated (thus already providing employers with incentives to reduce DI inflow). In other words, our analysis is informative on the added value of privatization of DI, as compared with a public system that has incentives by experience rating. Furthermore, firms in the Dutch public system have a different degree of experience rating. 'Large' firms from above a threshold of about 25 workers have an almost perfect degree of experience rating. Contrasting to firms that are classified as small, the direct premium gains from switching to provate insurance will thus be limited for large employers with relatively DI costs. In our analysis we will exploit this feature for a Regression Discontinuity design.

Throughout our analysis, we will argue that a proper statistical identification of selection and incentive effects requires an understanding of what information employers 
and private insurers had on worker disability risks, as well as their ability to exploit this information and to benefit from opting out of public insurance. This ability essentially stemmed from three sources: (i) knowledge on employer-specific disability risks; (ii) knowledge on the number of workers that are long-term absent and who have a high risk of claiming DI benefits in the near future; (iii) residual information on the short-term evolution of DI inflow rates. Using various specifications that exploit the longitudinal character of our data, we are able to control and test for the three types of self-selection, so as to obtain the incentive or 'moral hazard' effect of private insurance vis-à-vis public insurance.

The empirical outcomes are twofold. First, we find strong evidence for adverse selection effects with respect to the option to switch from public to private insurance. Employers opted out if this was most rewarding for them in reducing current DI premium rates, rather than that this contributed to lower future DI inflow rates (i.e. 'incentive effects'). Employers benefitted from opting out the most by anticipating low DI inflow rates in the years to come. Thus, selection effects stemmed from the employer's (and the insurer's) knowledge on the number of workers that were long-term absent and thus on the expected claim of DI benefits in the near future. The ability to exploit this information was highest among the group of employers that were classified as 'small' in the public DI, thus having the smallest degree of experience rating (compared to the other employers). For this group of small employers, imperfect experience rating in the public system rendered opting out most beneficial if indivual disability costs were low.

Second, when taking a broader perspective, an important empirical finding is that firms seemingly preferred higher insurance coverage than was the case in the public 
system. With private insurers that typically offered contracts with uniform DI premium rates, it seems that opting out to private insurance increased insurance coverage, particularly for medium-sized firms that were almost perfectly experience rated in the public system. This hypothesis is supported by using Regression Discontinuity analyses that exploit the cutoff between 'small' and 'large' firms in the experience rating system. We find firms that were confronted with an increase in the degree of experience rating when they switched from 'small' to 'large' to be 2 percentage-point more likely to opt out from public to private insurance. This suggests that these firms preferred to increase their insurance coverage by opting out from public insurance.

Our analysis adds to the broad empirical literature on employer experience rating incentives in DI and $\mathrm{WC}^{7}$, as well as to the more specific (and more limited) literature on the effects of opting out on DI costs. In this literature, it is often argued that the potential incentive effects of self-insurance can be inferred from experience rating effects with employers bearing all DI benefits costs - thus being 'perfectly experience rated ${ }^{8}{ }^{8}$ Similar to the findings for experience rating, one thus would expect self-insurance to reduce injury rates and lost injury days, but also to increase inappropriate claims management, such as opposing DI claims and appealing to DI claim awards - see Hyatt and Thomason (1998) and Tompa et al. (2012). In the current analysis, however, characterizing opting out as perfect experience rating would ignore the fact that opting out changed the type of insurance - with employers switching from public to private insurance providers. In light

\footnotetext{
${ }^{7}$ The use of experience rating is most well known in the context of WC in the US and Canada. To our knowledge, in Europe DI experience rating is used only in DI schemes in the Netherlands and Finland (Koning, 2009; Kyyrä and Tuomala,2013).

${ }^{8}$ For instance, Seabury et al. (2012) use self insurance as a proxy for experience rating.
} 
of the high degree of experience rating in the public scheme, private insurance providers may have offered contracts with a higher insurance coverage for employers. Thus, the privatization of disability insursance may have resulted in lower incentive effects.

This paper proceeds as follows. Section 2 explains the institutional setting of DI in the Netherlands, with an emphasis on the system of experience rating and conditions of opting out. Section 3 presents the data we use for our analysis. Section 4 discusses the empirical implementation of our analysis. Section 5 presents the estimation results, and the conclusions are drawn in Section 6.

\section{INSTITUTIONAL SETTING}

\subsection{DI in the Netherlands}

In the Netherlands, the provision of (either private of public) DI to their workforce is mandatory for all employers. Workers are entitled to apply for DI claims after a waiting period of two years of sickness absence. During the period of sickness, employers are responsible for the provision of reintegration activities and the continued payment of wages (Van den Bemd and Hassink, 2012). DI claims are assessed by the Dutch public social benefit administration (UWV), with DI benefits providing insurance for in general $70 \%$ of the loss of income due to impairments. Workers may thus receive partial DI benefits, which are supplemented by UI benefits if the residual earnings potential is not used to its full extent.

$<$ INSERT FIGURE 1 HERE > 
The Netherlands has long been characterized as the country with the most out-ofcontrol disability program of OECD countries (Burkhauser et al., 2008). Expressed as a percentage of the insured working population, DI enrolment increased rapidly to about $12 \%$ in the mid-1980s and then it remained more or less constant at this unprecedented level until the beginning of the $21^{\text {st }}$ century (see Figure 1). To understand the causes of these large and persistent enrolment rates, we stress two institutional features of the Dutch DI system that are different from systems in most other OECD countries and that have remained more or less similar over time (see also Koning and Lindeboom, 2015). First, the DI program covers all workers against all income losses that result from both occupational and non-occupational injuries. As is well known in the literature, including all workers against all medical contingencies introduces a potentially sizeable amount of screening error into disability determinations (Parsons, 1991). Second, wage payments for sick workers are continued in the waiting period of two years that precedes disability claims. These claims can be privately insured by employers. For employees in most economic sectors social partners have agreed upon (almost) full compensation in the sickness waiting period. In comparison to other OECD countrues, the Dutch sickness and DI claims system thus does not provide strong financial incentives for sick workers to resume work quickly.

It took until the beginning of this century to implement radical reforms that were effective in curbing DI inflow and DI enrolment. As Figure 1 shows, there has been a spectacular decline in the DI award and enrolment rate since 2002. One of the first reforms was the start of DI experience rating in 1998, combined with the introduction of 
opting out to private insurance of employers. ${ }^{9}$ To opt out from public insurance, employers had to post a bond or deposit of securities to warrant the continued payment of DI benefits that were already ongoing. Due to strict financial regulations, almost all employers were not capable of bearing this financial responsibility on their own (i.e. 'self-insurance') and therefore choose for private insurance. Opting out also implied that employers - and private insurers - became responsible for prevention and reintegration activities of their insured workers. Typically, the insurance contracts that were offered lasted for at least three years.

The evidence suggests that the enhancement of employer incentives in the Netherlands has contributed substantially and significantly to a reduction of DI inflow and DI enrolment in the Netherlands (Koning and Lindeboom 2015). First, Koning (2009) finds an estimate of DI experience rating pointing at a reduction of DI inflow of $16 \%$. Second, further reductions have been realized by the introduction of stricter legal responsibilities of employers and workers during the waiting period since 2002, as well as an extension of the waiting period from one to two years since 2004 - thus effectively increasing employer incentives. So far, this literature however does not provide insight on the extent to which opting out from public DI has contributed to the reduction of DI award rates.

\subsection{Experience rating}

We next consider the degree of experience rating in the public system. We argued earlier that employers may particularly have an interest in opting out from public experience

\footnotetext{
${ }^{9}$ We explain the system of experience rating in detail in sub-section 2.2.
} 
rating systems that are imperfect. Since 2006, experience rating in the Netherlands applies to DI costs of workers that are in the scheme for partially and/or temporary disabled individuals (WGA). For this scheme, imperfect rating stemmed from the use of minimum and maximum premiums.

To explain the setting that was applied, we start by calculating the individual DI risk of employers over a certain time window $\left(R i s k_{t}\right)$, measured in year $t$ :

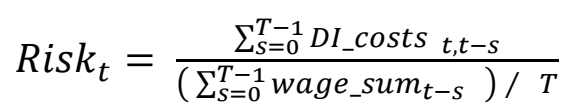

In equation [1], the variable DI_costs $s_{t, t-s}$ refers to the DI benefit costs at time $t$ of workers in the employer that entered into the DI scheme in year $t-s . T$ indicates the number of subsequent cohorts - or 'time window' - of disabled workers that are included in the nominator to calculate the DI risk - and thus are being experience rated. To reduce distortionary effects of volatility in the wage sum of employers, the consecutive wage sums are averaged over this time window. In the time period that is studied in this paper, the time window was equal to five years.

Conditional on the DI risk that is formulated in equation [1], equation [2] shows the social benefit administration calculated DI premiums $P$ for individual employers, measured at time $t$ :

$$
P_{t}=\min \left\{P_{\text {Minimum }}+\alpha \operatorname{Risk}_{t-2} ; \quad P_{\text {Maximum }}\right\}
$$


As the above equation shows, DI premiums are bounded by a minimum and maximum rate, which are indicated by $P_{\text {Minimum }}$ and $P_{\text {Maximum }}$. Basically, the minimum premium is paid by firms that had no DI inflow in the previous years. Due to administrative delays, DI premiums are based on actual DI risks with a time delay of two years. As a result, the premium that is needed to cover all DI costs at time $t$ differs from the disability risk at time $t-2$. This means that increases in the individual risk $\left(\operatorname{Ris}_{t}\right)$ will not lead to equal increases in $P_{t}$, but need to be multiplied by the correction factor $\alpha$. If the actual DI costs exceed (are lower than) the DI costs at time $t-2$, we have $\alpha>1(\alpha<1)$. For the period of investigation, the annual average DI premium rate of employers, measured as a percentage of the total wage sum of the employer, varied between $0.53 \%$ and $0.70 \%$.

As it is generally acknowledged that the employer's ability to control DI costs is more limited for smaller firms, the experience rating system was designed to limited the extent of financial risks for this group. Employers with a wage sum at time $t$ that was lower than 25 times the average wage sum per worker were classified as 'small'. This group constituted the vast majority of employers, with a maximum premium that was set equal to three times the actuarial premium rate. For the residual group of employers that were classified as 'large', the maximum premium, $P_{\text {Maximum }}$, was set equal to four times the actuarial premium. Next, for both groups the minimum premium, $P_{\text {Minimum }}$, was set so as to compensate for underpayments due to the maximum premium. ${ }^{10}$

To gauge the implications of using differentiated experience rating designs, Figure 2 shows the share of DI costs that is effectively paid by employers as a function of

\footnotetext{
${ }^{10}$ In the time period under investigation, the maximum premium of large employers varied between $1.47 \%$ and $2.1 \%$ of the wage sum.
} 
their wage sum. For expositional reasons, we assume that each worker earns the average wage sum that is used in the design of experience rating and evaluate the degree of experience rating that applies to one worker that enters into the DI scheme. Figure 2 shows that this degree increases from 5\% to about 50\% for employers with less than 25 workers. For employers with more than 25 workers, however, the cost of an additional worker in DI is almost fully experience rated (i.e., 'perfect experience rating'). As we will argue in Section 5, we can exploit this setup as an RD design to identify the effect of individual changes in the degree of experience rating.

\section{< INSERT FIGURE 2 HERE >}

\subsection{The opting-out decision}

Throughout our analysis, we argue that some employers could benefit from opting out, with two institutional settings that determined its relative attractiveness. First, the lower the degree of experience rating, the more room there was for employers with low DI costs to reduce insurance premiums by switching to private insurers. We will show that it comprises the group of small firms for which the size of the workforce was below a threshold of about 25 workers. Second, switching from public to private insurance required the expected DI costs of current enrollees to be capital-funded, thus imposing interest costs on employers and private insurers. Thus, the imposition of these "tail charges' essentially aggravated the effect of experience rating - that is, it decreased the relative attractiveness to opt out for employers without workers that were already enrolled in DI. 
We stated earlier that experience rating for smaller firms was imperfect. The vast majority of these firms - ranging from 93 to $98 \%$ over the years - had no DI benefits that were assigned to them, causing them to pay the minimum premium of $0.40 \%$ of the wage sum in 2007. Of the remaining group of employers with DI benefits that were assigned to them, virtually all paid the maximum premium. The experience rating system for small employers thus had two effective premium levels that were used. Consequently, private insurers had the opportunity to offer contracts to small employers with DI premium rates that were lower than those from the public social benefit administration. This was particularly rewarding if employers had no DI enrolment and no long-term sick listed workers at all at that time. ${ }^{11}$ More strikingly, Cuelenaere et al. (2013) show that contracts for small employers typically had premiums that were set at the level of (two-digit) sectors, thus not including experience rating incentives. This means that opting out led to a decrease in the employer incentives to prevent DI costs, with - next to adverse selection effects - risk aversion as another determinant of the opting-out decision.

Because employers paid premiums that were generally close to the DI benefit costs that could be assigned to them, cross-subsidies (among employers) were less sizeable for this group of employers. More specifically, underpayments due to the maximum premium were considerably smaller and the resulting minimum premium was lower as well. This limited the room for adverse selection. For this group, the arguments for opting out thus were probably different than lowering DI premiums by selection. ${ }^{12}$

\footnotetext{
${ }^{11}$ Furthermore, private disability insurance could be combined with insurance for the first two years of sickness absence.

${ }^{12}$ In this respect, Cuelenaere et al. (2013) characterize the contracts between private insurers and larger employers as 'taylor-made', but also as highly non-transparent.
} 
It is generally acknowledged that the market for private insurance of DI in the Netherlands can be characterized as highly competitive, also in the time period under investigation in this paper. Although the three largest private insurance companies constituted a market share of about $65 \%$, private insurers were typically willing to incur substantial financial losses in order to increase their market shares (Cuelenaere et al., 2013). This strategy was obviously most rewarding for large employers, which were offered large premium discounts. ${ }^{13}$ At the same time, survey outcomes among employers suggest that prevention and reintegration activities of private insurers were limited. In particular, employers with disabled workers did not experience an increase in activities, compared to public insurance by UWV in earlier years. It thus suggests that competition among private insurers of DI was largely driven by premium differentials, rather than by activities that aimed to reduce DI costs of the employers.

\section{DATA}

\subsection{Employer-level data}

For our empirical analysis, we use annual administrative employer data of UWV on the disability insurance status (public or private), the DI award (i.e., the annual inflow), the DI enrolment (i.e., the total disability stock) and some employer characteristics (i.e., economic sector, age and gender composition of the work force) - all measured from 2007 to 2011. In principle, the data set covers all employers in the Netherlands with wage

\footnotetext{
${ }^{13}$ As we will show in Section 3, we observe the largest increases in the probability of private insurance for the group of employers with more than 250 insured workers.
} 
payments for one or more employed workers. The statistics of the data are displayed in Table 1, both for the full sample as well as a balanced panel of 139,298 employers.

\section{< INSERT TABLE 1 AND FIGURE 3 HERE >}

Table 1 shows that, on average, $29.6 \%$ of all employers had opted out from public insurance to private insurance in the time period of investigation. This percentage is somewhat higher in the balanced sample (34.6\%), as this does not include new employers (the so-called 'starters') that are publicly insured by UWV by default. Because of the sickness waiting period of two years, it should be stressed that new employers could not have any DI inflow in the first two years of their existence. We therefore concentrate on the selected (balanced) sample of employers that are observed in all years. As a result, we lose $54 \%$ of the annual employer observations that are in the unbalanced panel, covering $16 \%$ of the total sample of workers with fixed-term contracts. ${ }^{14}$

Figure 3 shows that the fraction of private insurance has initially been most prominent for employers with 25 insured workers or less. In addition, we observe a rise in private insurance across the board between 2007 and 2010. Most notably, the share of private insurance has increased from 8 to about $40 \%$ for employers with more than 99 insured workers. As argued in Section 2, this mirrors the fact that private insurers aimed at increasing their insured population, particularly by focusing on employers with many insured workers in particular.

\footnotetext{
${ }^{14}$ From a methodological perspective, using the balanced panel instead of the total, unbalanced panel provides us with more efficient fixed effect and first--difference estimates (see Section 4). Furthermore, it should be noted that the vast majority of employers that are excluded are observed only one or two years.
} 
In our data, employer DI award and DI enrolment rates are measured as a percentage of the insured workers per employer in year $t-1$. In this respect, it should be noted that DI employer-level inflow rates and DI enrolment rates are substantially lower than the worker-level DI rates that were shown in Figure 1. First, since 2006 experience rating was limited to the scheme of partially and/or temporarily disabled workers (WGA) only; it thus excluded the scheme for permanently and fully disabled (IVA). Second, and related to the previous argument, DI enrollment that was recorded for the new WGA scheme still had to accumulate over time since 2006. Third, DI recipients are not assigned to employers that ceased to exist. ${ }^{15}$

\subsection{Exploring the relation between risks and private insurance}

Key to the empirical literature on insurance markets is the presence of a coverage-risk relationship as a necessary condition for adverse selection and/or moral hazard to exist (Cohen and Spiegelman, 2010). Typically, insurance coverage is measured at the level of individual consumers. In the current paper, however, the distinction between insurance coverage and DI risks concerns employers for which the effects of the removal of public insurance are ambiguous. In light of the experience rating system, opting out from public to private insurance may have increased insurance coverage, rather than lowering it. Employers may thus have chosen to opt out to reduce their financial risks, while lowering their incentives for prevention and reintegration.

\footnotetext{
${ }^{15}$ To finance DI benefits of workers of employers that ceased to exist, a higher minimum premium in the experience rating system was needed.
} 


\section{< INSERT FIGURES 4 AND 5 AND TABLE 2 HERE >}

Figure 4 sheds more light on the relation between DI risks and the prevalence of private insurance by presenting a scatter plot of annual DI inflow rates and the share of employers with private insurance, averaged over the 69 sectors in our sample. The figure suggests that private insurance was more prominent in sectors with higher rates of DI inflow - which may seem at odds with economic intuition. To explain this pattern, however, one should acknowledge the fact that variation in DI inflow rates within sectors was probably more important in creating room for adverse selection. Sectors with high incidence of DI and a higher variation of DI inflow rates may thus have provided more room for employers and insurers to take advantage of adverse selection. We return to this issue in more detail in Section 5.

We also explored the relation between DI risks and insurance status at the individual-employer level, using two proxies for the DI risk of employers: the annual DI inflow rate of workers that are employed at a specific employer and the annual rate of workers of an employer that are enrolled in DI (i.e., the DI enrolment rate). For each year in our sample, we regressed these two variables on the employer insurance status, for which we controlled for 10 employer size dummies, 68 sector dummies and 4 rates of worker composition (gender and age). To obtain the relative differences, the coefficients on the risk differentials between employers with public and private insurance were divided by the average risk in the sample of prublicly insured employers in the corresponding year. Figure 5 displays the resulting pattern of the relative differentials, both for employers that were classified as small and large, respectively. Recall that small 
firms were classified as small (large) when having a wage sum that is smaller (larger) than 25 times the average annual wage sum.

The panels in Figure 5 reveal that the evolution of the relative risk differs between small and large employers. For small employers, we observe a gradual increase in the risk differential, both for the disability inflow rate and the disability enrolment rate as proxies for DI risk. The DI inflow of privately insured employers was about 15\% lower in 2007 than for publicly insured employers and this difference has increased to $25 \%$ in 2011 . This pattern is stronger for the evolution of DI enrolment among small employers, adding up to a rate that was about $40 \%$ lower in 2011 than that for publicly insured employers.

To test whether adverse selection contributed to these changes, Table 2 shows the coefficient estimates of pooled OLS estimation of the decision of opting-out to private insurance in the years 2008 to 2011, both for the samples of small (first column) and large employers (second column) that had not opted out so far. For the sample of employers that are classified as 'small', a one-percentage point increase in the employer DI enrolment rate in the previous year decreased the probability of opting out with 0.12 percentage point.$^{16}$ This indicates that selection contributed to the increased differential in DI enrolment rates between private and public insurance. This finding is supported by more qualitative evidence from websites of Dutch providers of DI that advice Dutch employers on the decision of opting out from public DI. As an example, we refer to the website of www.vanpublieknaarprivaat.nl in which employers are simply advised to opt

\footnotetext{
${ }^{16}$ As long as the DI premium is not bounded by the maximum premium, a one percentage-point increase in the DI enrolment rate would imply an increase in the DI premium with $0.7 \%$-point.
} 
out only if they have no enrolees and no workers that have been in the sickness waiting period for more than six months.

Contrasting to these findings, we observe a downward trend in the risk diffential of large employers that had opted out. For both the DI inflow and the DI enrolment rate, the difference with respect to the public premium rates decreased from about $35 \%$ to $10 \%$ in the most recent year. This suggests employers and private insurers took less advantage of adverse selection than in the first years of the experience-rating system (Koning, 2009). ${ }^{17}$ When considering the model results that are presented in the second column of Table 2, we also find evidence in this direction. That is, there is no significant relation between the lagged DI enrolment rate and the probability of switching to private insurance.

\section{EMPIRICAL IMPLEMENTATION}

In this paper, adverse selection can be defined as the ability of private insurers and employers to exploit risk information by opting out, with the aim to lower employer DI costs. ${ }^{18}$ Private insurers had the advantage to exploit risk information, whereas the public benefit administration did not. In what follows, we argue that this potential advantage essentially originated from three sources: (i) employer information that was constant over time, e.g. on employer-specific DI risks at the workplace; (ii) private information on

\footnotetext{
${ }^{17}$ Prior to the introduction of the new DI schemes in 2006, DI benefit costs that were experience rated were much higher. Therefore, a higher minimum premium was needed for large employers to cover underpayment due to the maximum premium.

18 This definition is broader than the common definition in the literature, which states that policyholders may be better informed than insurers about probability or size of risks (Cohen and Spiegelman, 2010).
} 
current sickness absence, so as to anticipate DI inflow rates in the period ahead; (iii) remaining short-term trends in DI inflow and DI enrolment that employers could anticipate on, particularly when serial correlation in DI risks was important. As we will argue later on, the role of these mechanisms is likely to differ between small and large employers.

We propose a research strategy that systematically takes account of these three types of possible adverse selection. Our key endogenous variable is the DI inflow rate; this variable is most closely linked to the current effort that is spent to prevent DI inflow. We start by specifying the following model:

$$
D I \_i n f l o w_{i t}=\gamma I\left(O p t_{-} o u t_{i t}=1\right)+X_{i t} \beta+S_{i}+Y_{t}+\varepsilon_{i t}
$$

with $i(i=1 . ., I)$ indicating the employer and $t$ representing the year in our sample $(t=$ $1, \ldots, T)$. The parameter of interest, $\gamma$, describes the effect of opting out to private insurance; the corresponding incidence of private insurance is represented by the dummy variable I. $X_{i t}$ is a vector that includes the employer size, gender and age composition of employers; all of these variables are constructed as categorical dummy variables. Vector $\beta$ describes the effect of these characteristics on the employer DI inflow rate. $S_{i}$ represents a sector specific effect that is captured by a dummy. $Y_{t}$ describes year-specific effects as a piecewise constant function. Finally, we assume the error term $\varepsilon_{i t}$ to be 
independently and identically distributed with $\left(0, \sigma^{2}\right) \cdot{ }^{19}$ When estimating equation [3], we allow for clustering the standard errors at the level of the individual employer.

As a first extension, we add employer-fixed effects $u_{i}$ to equation [3], so as to take account of time constant characteristics that affected DI risks of employers:

$$
\text { DI_inflow } i t=\gamma I\left(O p t_{-} o u t_{i, t}=1\right)+X_{i t} \boldsymbol{\beta}+Y_{t}+u_{i}+\varepsilon_{i t}
$$

Equation [4] takes account of the fact that private insurers may have been able to exploit information on specific prevention and reintegration policies that were followed by employers, or employer-specific risks that were not observed or registered by the public insurance organization. Private insurers may have triggered employers to reveal this information, offering premium reductions and thus contributing to adverse selection.

Second, we consider the possibility that employers and private insurers could benefit from opting out of public DI if they anticipated low DI inflow rates in the next year. This ability stems from the sickness waiting period that precedes DI claims. Conditional upon the rate of absence in the waiting period, employers - particularly the smaller ones without any absent worker - could anticipate the number of DI claimants in the year ahead to some extent. If employers took advantage of anticipation effects in this way, one would expect the short-term impact of opting out to be biased towards zero. We

\footnotetext{
${ }^{19}$ Although the majority of annual employer DI inflow rates are equal to zero, we argue that the sample size is sufficient to maintain the assumption that the error terms are identically distributed. To test for this, we re-estimated all model specifications using a (nonlinear) fractional Logit specification instead of the linear model specification. The results are shown in column (ii) of Tables 3 and 4.
} 
therefore re-specify equation [4] by taking the lagged value of the private insurance variable as the key explanatory variable:

$$
D_{-} \text {inflow }_{i t}=\gamma I\left(\text { Opt_out }_{i, t-1}=1\right)+X_{i t} \boldsymbol{\beta}+Y_{t}+u_{i}+\varepsilon_{i t}
$$

This specification captures the notion that incentive changes due to opting out could only affect the DI inflow with a delay of one year, while the DI inflow in the first year resulted from the number of sick listed workers that originated in the year prior to opting out. As such, we rule out anticipation effects that stem from the sickness waiting period.

Our final concern is that employers and private insurers had access to other sources of information that helped them in anticipating low DI inflow rates in the years ahead. Typically, if there would be serial correlation in DI inflow rates, employers could anticipate the likelihood of maintaining future DI inflow rates that were sufficiently low to benefit from opting out. In this case, the strict exogeneity assumption that is needed for consistent FE estimates of the incentive effect would be violated. This assumption states that opting out should not be driven by future values of the DI inflow rates.

To test for the strict exogeneity assumption, we use a simple test that has been proposed by Wooldridge (2010): we compare fixed effect (FE) and first differenced (FD) estimates of our model, arguing that these estimation methods have different probability limits in case of anticipation effects. More specifically, we test on misspecification of our model that would stem from anticipation of the opting-out decision on future values of the errors terms. We thus reformulate and estimate equation [5] in terms of firstdifferenced variables: 


$$
\Delta D I \_ \text {inflow }{ }_{i t}=\gamma \Delta I\left(\text { opt_out }_{i, t}=1\right)+\Delta X_{i t} \boldsymbol{\beta}+Y_{t}+\Delta \varepsilon_{i t}
$$

Next, the comparison of FE and FD estimates is essentially a test on the hypothesis that there are no remaining sources of self-selection in our model. This would imply that the coefficient estimate of $\gamma$ can be considered as the 'true' incentive effect.

\section{ESTIMATION RESULTS}

Table 3 and Table 4 display the estimation results of equations [3] to [6] for small employers and large employers, respectively. In both tables, we start with presenting the coefficient results from specifications that uncover the relative risk of private versus public insurance - see columns (i) to (iii). In addition, columns (iv), (v), and (vi) show the estimation results of equations [4], [5], and [6], respectively. The comparison of columns (v) and (vi) provides us with a test on remaining anticipation effects.

\section{$<$ INSERT TABLES 3 AND 4 HERE >}

\subsection{Small employers}

For the sample of employers that are classified as small by the public social benefit administration, we find the DI inflow rate per worker to be about $0.05 \%$-point lower in case of private insurance than for public insurance. This estimate, which may reflect either selection or incentive effects, is equal to about $25 \%$ of the average DI inflow rate of small employers in our sample. The marginal effect estimate does not change if we do 
not impose linearity assumptions, but use a fractional Logit specification instead. We also re-estimated the OLS specification [3] on the annual change of employer DI enrolment rates. As column (iii) of Table 3 shows, this yields a parameter estimate that is close to the coefficient estimate of the DI inflow rating, suggesting that changes in the DI enrolment rate are driven by DI inflow rates rather than changes in outflow rates.

Allowing for employer fixed effects (equation [4]) does not substantially or significantly alter the coefficient effect of private insurance - see column (iv) of Table 3 . Stated differently, the 'within-variation' in insurance statuses for the sample of employers that have opted out in the time period of consideration - constituting about $15 \%$ of our sample - leads to coefficient effects on the employer DI inflow rates that are almost equivalent for the pooled OLS estimate for the full sample. This indicates that private insurers and policyholders were not able or did not exert effort to identify and attract smaller employers with low DI risks by exploiting individual specific characteristics that were constant over time. ${ }^{20}$ Also, the comparison between OLS and FE suggests that insurers did not benefit from attracting firms without past inflow into the DI scheme; otherwise, the relative effect of private insurance would be lower in case of FE estimation..$^{21}$

We next adapt our model by using lagged variable values of the insurance status (equation [5]). Column (iv) of Table 3 shows this yields a coefficient estimate that is

\footnotetext{
${ }^{20}$ This finding is in line with the survey evidence of Cuelenaere et al. (2013), who argue that private insurers used sector-specific DI premium rates, rather than amending further refinements that took account of employer-specific risks.

${ }^{21}$ In this context, one would expect a regression-to-the-mean effect to occur: if insurers focussed on employers with DI inflow rates in the past, one would expect these rates to rise in the years after opting out.
} 
positive and statistically insignificant. This suggests that employers anticipated and exploited low DI inflow rates in the year that was ahead. To put it more strongly, the relation between private insurance and DI inflow can be fully explained by anticipatory effects in the sickness period that precedes inflow into DI. Finally, we find our FE and FD incentive estimates to be almost equivalent - see columns (v) and (vi). This indicates that further anticipation effects on future DI inflow rates are probably not very important. In sum, we cannot reject the null hypothesis that the incentive effect of private insurance is equal to zero.

\subsection{Large employers}

We argued earlier that the room for adverse selection was probably smaller for employers that were classified as large than for those that were classified as small. For this group, experience rating for large employers was close to perfect, thus limiting the ability of private insurers to focus on and benefit from employers with low current DI costs. With this in mind, Table 4 still shows that DI inflow rates of employers with private insurance where $0.025 \%$-point lower than those who with public insurance, which is equal to $12 \%$ of the average DI inflow rate in our sample. Similar to the sample of small employers, this differential is robust with respect to a non-linear specification. Also, the DI inflow rates - not the outflow rates - are the dominant contributor to changes in the DI enrolment rates; see columns (ii) and (iii), respectively. Our FE estimates in column (iv) also suggest that private insurers and policyholders were not able to identify and exploit individual employer specific characteristics that were constant over time. 
Similar to the sample of small employers, our results indicate the presence of anticipation effects that drive the decision to opt out from public insurance. Using lagged values of the insurance statuses even yields positive and borderline significant incentive effects for the sample of large employers - both in case of FE and FD estimation. One explanation for this may be that private insurance lowered the incentives the employers had to reduce DI inflow to some extent, rather than increasing them. We will examine this issue in more detail in sub-section 5.4.

\subsection{Additional analyses}

To analyze our effect estimates in greater detail, Table 5 shows our key results for various samples of our data and for specifications with interacted effects. In the table, the first column denotes the estimation results that are obtained from pooled OLS regression, whereas the second column denotes estimation results that do control for unobserved and anticipatory effects. Combining these two estimates thus provides insight in the room for selection that employers and private insurers benefitted from.

Depending on the average size employers had in our panel in the time period of investigation, Table 5 starts by stratifying our sample to detect heterogeneity in employer size effects. Again, it appears that the ability to exploit deviations from the average DI inflow rate was largest for the smaller employers. This confirms the anecdotal evidence suggesting that private insurers were keen on attracting small employers without any disabled and long-term sick-listed workers; pursuing this strategy was less obvious for employers with many workers. 


\section{< INSERT TABLE 5 HERE >}

Interestingly, we find weak evidence for positive incentive effects - i.e., increased DI inflow due to private insurance - for employers that are medium sized, with 10-24 insured workers and 50-99 insured workers, respectively. This suggests that the transition from public to private insurance caused incentives to decrease, with employers responding by lowering their prevention effort. Table 5 also shows that the incentive estimate was largest for employers in the public and semi-public sector. The vast majority of this sample consisted of non-profit organizations that are active in the cure and care sector. One explanation may be that the non-profit organizations that opted out had a higher preference for stable DI costs, compared to for-profit organizations.

Finally, we investigated whether our estimation results differed between low and high-risk employers. To avoid endogeneity problems in characterizing the DI risks, we took the sectoral value averages of DI inflow rates in the period from 2007 to 2011 , employing 69 sectoral indices that were used by the social benefit administration. ${ }^{22} \mathrm{We}$ next estimated the interacted effect of these value averages with the private insurance dummy - see the lower panel of Table 5 for the corresponding results for large and small employers, respectively. For both small and large employers, the difference between DI inflow rates of private insurance and public insurance decreases with respect to the

\footnotetext{
${ }^{22}$ It should be noted that value averages per sector are obtained by weighing employers by the number of insured workers they had. When following this strategy, sectors with the highest annual DI inflow rate are, in successive order, the cleaning industry $(0.76 \%)$, the hotel and catering industry $(0.74 \%)$, and taxidrivers $(0.40 \%)$. Sectors with the lowest annual DI inflow rates include the telecommunication industry $(0.059 \%)$, business services $(0.074 \%)$, and transport to airport $(0.076 \%)$.
} 
sectoral value average. When combining these findings with the estimates that control for anticipatory effects, it appears that the room that employers and private insurers had for adverse selection was higher in high-risk sectors. Stated differently, these sectors provided private insurers as well as the employers with the ability to benefit from premium reductions.

\subsection{Assessing the impact of experience rating: small versus large employers}

Our findings indicate that switching from public to private insurance did not contribute to a decrease in employer DI inflow rates. Particularly for medium-sized employers (with a wage sume that is larger than 25 times the average wage sum in a particular year), we conjectured that opting out to private insurance may have led to an increase in insurance coverage and, consequently, a decrease in incentives to prevent DI inflow. Following this line of reasoning, one would expect employers to respond to increases or decreases in experience rating incentives, with higher incentives increasing the likelihood of moving to private insurance. Such increases in the degree of experience rating were relevant for employers that were no longer registered as small by the public benefit administration but as large. Likewise, decreases in the number of insured workers may have led to a decrease in the degree of experience rating for some employers, as they were no longer registered as large but as small.

< INSERT TABLE 6 HERE > 
To analyze the consequences of these switches in size status, we estimated various employer-level fixed effects models (see Table 6). The intuition behind this approach is that the effect of experience rating incentives - which depends on the size status - is estimated for 'within-variation' of employers that have both been qualified as 'small' and 'large' for some time between 2007 and 2011. This means that our effect estimate is inferred from $3.0 \%$ (25,889 employers) that had their size status changed over time. As the first column of Table 6 shows, the number of insured workers for this group was about 5 persons higher in the years that they were qualified as large than in the years that they were qualified as small. Thus, employers had a similar employer size if they were in the control group of 'small' employers as if they were in the treatment group of 'large' employers. Stated differently, this lends credence to the idea that any changes in outcome variables will follow from changes in the experience rating status, rather that employer size. The second column of Table 6 shows that the probability of private insurance for employers increases with 2\%-point if they faced higher experience rating incentives. This lends credence the idea that they felt an increased need for insurance coverage. Finally, in the third column of Table 6 we add (five) polynomials for the wage sum of employers. As such, our analysis can be characterized as a Regression Discontinuity regression that controls for (changes in) the wage sum around the cutoff point that determines the experience rating status. These estimation results show similar outcomes as in the model without additional controls, which is in line with finding that the employer size variation around the critical point was limited. 


\section{CONCLUSION}

Our analysis provides consistent empirical evidence that private insurers succeeded in attracting employers with low DI premium rates. This particularly applied to smaller employers that were expected to have low DI enrolment in the years ahead. Insurers and employers thus took advantage of the imperfect experience rating in the public insurance scheme, with a strategy that was essentially twofold.

First, private insurers targeted small employers without - or with a few - workers that were enrolled in DI by offering lower premium rates for this group. In light of the extensive time window of experience rating and low recovery rates, private insurers thus avoided high initial costs that were needed to provide funding for the DI recipients that were already enrolled. This specific way of selection by private insurers was reflected in the lower rate of DI enrolment under private insurance, but not in the lower rate of DI inflow after having opted out to the private insurers. As a second screening device, private insurers focused on employers without workers that were listed as long-term sick. As a two-year period of sickness absence preceded DI claims, these employers had low or zero expected DI benefit costs in the first year of private insurance, providing them with a substantial advantage compared to public insurance. This effect particularly held for smaller employers.

Our analysis shows that private insurers primarily took advantage of adverse selection, rather than by aiming at reductions in DI inflow rates (i.e. 'incentive effects'). Clearly, employer incentives were already high in the two-year sickness waiting period that precedes the disability claims assessment, leaving little room for further improvements in this period. Another explanation is that private insurance - with 
premiums that were mostly set at sectoral levels - provided more coverage and less employer incentives than the public experience rating system. For some groups in our sample - particularly employers with 25 to 100 insured workers - there even is weak evidence that opting out increased DI-inflow rates.

One common aspect of these findings is that settings of experience rating in the public system of DI have largely determined the potential for selection and incentive effects for opting out of public DI. Probably the most important lesson in this respect is that experience rating may prevent mixed DI systems from instable situations where large groups of firms move from public to private insurance at the same time, or reverse. Without any experience rating in the public DI system, it is likely that employers with low DI risks sort into private insurance. Consequently, it increases the minimum premium to the remaining employers in the public system and it further increases the attractiveness of opting out for employers without any DI costs. However, the implication of our analysis is that experience rating in the public DI system mitigates the potential merits of opting out. 


\section{REFERENCES}

Autor, D., Duggan, M. (2006), The Growth in the Social Security Disability Rolls: A Fiscal Crisis Unfolding, Journal of Economic Perspectives, 20(3), 71-96.

Autor, D., Duggan, M. Gruber, J. (2014), Moral Hazard and Claims Deterrence in Private Disability Insurance, American Economic Journal: Applied Economics, 6(4), 110141.

Burkhauser, R., Daly, M.C., McVicar, D., Wilkins, R. (2014), Disability benefit growth and disability reform in the US: lessons from other OECD nations, IZA Journal of Labor Policy 3 (4), (20 February 2014).

Butler, R.J., Worall, J.D. (1993), Self Insurance in Workers' Compensation, In: Workers ' Compensation Insurance: Claim Costs, Prices, and Regulation, edited by David Durbin and Phillip S. Borba. Boston: Kluwer Academic Publishers

Butler, R.J. (1996), Moral Hazard Differences between Tort and Workers'Compensation, The Journal of Risk and Insurance, 63(3), 405-433.

Chiappori, P-A, Salanié, B. (2000), Testing for Asymmetric Information in Insurance Markets, The Journal of Political Economy, 108(1), 56-78.

Cohen, A., Siegelman, P. (2010), Testing for Adverse Selection in Insurance Markets, The Journal of Risk and Insurance, 77(1), 39-84.

Cuelenaere, B., Zwinkels, W.S., Veerman, T.J., Molenaar-Cox, P.G.M. (2013), Ontwikkeling Hybride Financiering WGA, ASTRi Beleidsonderzoek en -advies.

Dionne, G., Fombaron, N., Doherty, N. (2012), Adverse Selection in Insurance Contracting, Cahier de recherché 12-31, CIRPEE.

Hyatt, D., Thomason, T. (1998), Evidence on the Efficacy of Experience Rating in British Columbia. A Report to The Royal Commission on Workers' Compensation in British Columbia.

Jong, Ph. De, Lindeboom, M. (2004), Privatisation of sickness insurance: Evidence from the Netherlands, Swedish Economic Policy Review 11, 11-33.

Koning, P. (2009), Experience Rating and the Inflow into Disability Insurance, De Economist, 157(3), 315-335.

Koning, P., Lindeboom, M. (2015), The Rise and Fall of Disability Insurance Enrollment in the Netherlands, Journal of Economic Perspectives, 29(2), 151-172. 
Krueger, A.B. (1990), Workers' Compensation Insurance and the Duration of Workplace Injuries, Working Paper no. 3253, National Bureau of Economic Research, Cambridge, Massachusetts.

Kyyrä, T., Tuomala, J. (2013), Does Experience Rating Reduce Disability Inflow? IZA Working paper 7344.

Morantz, A. (2010), Opting Out of Workers' Compensation in Texas: A Survey of Large, Multistate Non-subscribers. In Kessler, D. (ed): Regulation vs. Litigation:

Perspectives from Economics and Law, Cambridge, MA: National Bureau of Economic Research.

New Street Group (2012), Workers' Compensation Opt-Out: Can Privatization Work?

The Texas Experience and the Oklahoma Proposal, November 2012.

OECD (2010), Sickness, Disability, and Work: Breaking the Barriers. A Synthesis of Findings Across OECD Countries, OECD: Paris.

Parsons, D. (1991), Self-Screening in Targeted Public Transfer Programs, Journal of Political Economy. 99(4), 859-876.

Seabury, S.A., McLaren, C.F., Reville, R.T., Neuhauser, F., Mendeloff, J. (2012), Workers' Compensation Experience Rating and Return to Work, Policy and Practice of Health and Safety, 10(1), 97-115.

Shields, J., Lu, X., Oswalt, G. (1999), Workers' Compensation Deductibles and Employers' Costs, The Journal of Risk and Insurance, 66(2), 207-218.

Thomason, T. (1993), Permanent Partial Disability: Probability and Costs, Journal of Risk and Insurance, 60(4): 570-590.

Tompa E., Cullen K., McLeod C. (2012), Update on a Systematic Literature Review on the Behavioural Incentives of Experience Rating, Policy and Practice in Health and Safety, 10(2), 47-65.

UWV, (2013), Gedifferentieerde premies WGA en ZW, Amsterdam.

Van den Bemd, J., Hassink, W.H.J. (2012), Privatization of the Absenteeism Scheme: Experiences from The Netherlands, Frisch Report 2/2012, Frisch Centre Oslo. Wooldridge, J.M. (2010), Econometric Analysis of Cross Section and Panel Data, MIT Press: Cambridge, second edition. 
Table 1: Full and Selected Employer Sample Statistics (standard deviations in parentheses)

\begin{tabular}{|c|c|c|c|c|}
\hline \multirow[b]{2}{*}{ Private insurance } & \multicolumn{2}{|c|}{ Full Sample } & \multicolumn{2}{|c|}{$\begin{array}{l}\text { Selected Sample: } \\
\text { balanced Panel }\end{array}$} \\
\hline & 0.296 & $(0.456)$ & 0.346 & $(0.476)$ \\
\hline DI inflow rate per insured worker $(\mathrm{fte})^{\mathrm{a}}$ & 0.174 & $(2.504)$ & 0.197 & $(2.407)$ \\
\hline DI enrolment rate per insured worker (fte) ${ }^{\mathrm{a}}$ & 0.731 & $(62.00)$ & 0.533 & $(4.212)$ \\
\hline \multicolumn{5}{|l|}{ Years } \\
\hline 2007 & 0.169 & $(0.375)$ & 0.200 & $(0.400)$ \\
\hline 2008 & 0.205 & $(0.404)$ & 0.200 & $(0.400)$ \\
\hline 2009 & 0.207 & $(0.405)$ & 0.200 & $(0.400)$ \\
\hline 2010 & 0.208 & $(0.406)$ & 0.200 & $(0.400)$ \\
\hline 2011 & 0.211 & $(0.408)$ & 0.200 & $(0.400)$ \\
\hline \multicolumn{5}{|l|}{ Premium setting } \\
\hline Wage sum (in Euros) & 297,686 & $(3,238,142)$ & 582,708 & $(4,756,810)$ \\
\hline Starters (fraction) & 0.063 & $(0.243)$ & 0 & (.) \\
\hline Small employers ${ }^{b}$ & 0.942 & $(0.233)$ & 0.875 & $(0.331)$ \\
\hline Large employers ${ }^{b}$ & 0.058 & $(0.233)$ & 0.125 & $(0.331)$ \\
\hline Insured workers per employer (persons) & 12.10 & $(107)$ & 22.5 & $(156)$ \\
\hline Insured workers per employer (fte) & 10.07 & $(110)$ & 19.71 & $(161)$ \\
\hline \multicolumn{5}{|l|}{ Worker composition, measured per employer } \\
\hline Female & 0.447 & $(0.397)$ & 0.403 & $(0.348)$ \\
\hline Age: $<35$ year & 0.468 & $(0.364)$ & 0.435 & $(0.296)$ \\
\hline $35 \leq$ Age: $<45$ & 0.248 & $(0.287)$ & 0.267 & $(0.226)$ \\
\hline $45 \leq$ Age $<55$ & 0.188 & $(0.266)$ & 0.200 & $(0.212)$ \\
\hline $55 \leq$ Age $<65$ & 0.096 & $(0.207)$ & 0.097 & $(0.161)$ \\
\hline \multicolumn{5}{|l|}{ Sectors } \\
\hline Agriculture & 0.067 & $(0.251)$ & 0.066 & $(0.249)$ \\
\hline Construction & 0.062 & $(0.241)$ & 0.075 & $(0.264)$ \\
\hline Industry & 0.124 & $(0.329)$ & 0.157 & $(0.364)$ \\
\hline Trade & 0.261 & $(0.439)$ & 0.247 & $(0.431)$ \\
\hline Transportation & 0.036 & $(0.187)$ & 0.043 & $(0.203)$ \\
\hline Services & 0.200 & $(0.400)$ & 0.195 & $(0.396)$ \\
\hline Temporary work agencies & 0.008 & $(0.091)$ & 0.006 & $(0.079)$ \\
\hline Health care & 0.113 & $(0.317)$ & 0.106 & $(0.308)$ \\
\hline Education & 0.004 & $(0.060)$ & 0.007 & $(0.084)$ \\
\hline Public sector & 0.002 & $(0.042)$ & 0.003 & $(0.058)$ \\
\hline Other & 0.122 & $(0.327)$ & 0.093 & $(0.291)$ \\
\hline \# Observations & $1,513,59$ & & 696,495 & \\
\hline \# Employers & 404,139 & & 139,299 & \\
\hline
\end{tabular}

${ }^{a}$ Rates are expressed as percentages from the insured worker per employer.

${ }^{\mathrm{b}}$ Small (large) employers are defined as having a wage sum at time $t$-2 that is smaller (larger) than the average wage sum in that year, multiplied by 25 . 
Table 2: Pooled LPM estimation results of opting-out decision to private insurance (2008-2011). Clustered standard errors in parentheses.

\begin{tabular}{lll}
\hline & Small employers & Large Employers \\
\hline DI enrolment rate, t-1 & -0.0012 & 0.0011 \\
& $(0.00014)^{* * *}$ & $(0.0010)$ \\
Year $=2009$ & -0.030 & -0.030 \\
& $(0.00081)^{* * *}$ & $(0.0024)^{* * *}$ \\
Year $=2010$ & 0.082 & 0.067 \\
& $(0.0014)^{* * *}$ & $(0.0034)^{* * *}$ \\
Year $=2011$ & 0.010 & 0.0032 \\
& $(0.0011)^{* * *}$ & $(0.0030)$ \\
Employer size dummies $(\#=10)^{a}$ & $\mathrm{X}$ & $\mathrm{X}$ \\
Worker composition controls $^{\mathrm{b}}$ & $\mathrm{X}$ & $\mathrm{X}$ \\
Sector dummies $(\#=10)^{\mathrm{c}}$ & $\mathrm{X}$ & $\mathrm{X}$ \\
${ }^{\mathrm{R}}$ squared & & 0.031 \\
\# Observations & 317,178 & 55,388 \\
\hline
\end{tabular}

$*, * *$, and $* * *$ denote significance of the parameter estimate at $10 \%, 5 \%$, and $1 \%$, respectively.

${ }^{a}$ We estimate the effect of employer size as a step function with the following intervals: 0-4, 5-9, 10-14, $15-19,20-24,25-34,35-49,50-74,75-99,100-250$, and $>250$ insured workers. Note that not all dummy variables are identified when stratifying upon small and large employers.

${ }^{\mathrm{b}}$ Worker composition controls include the share of female workers, as well as the shares of the following age categories: $<35,35-44,45-54$, and $>55$ or older.

${ }^{\mathrm{c}}$ Sector dummies are used for agriculture, construction, the industrial sector, trade, transportation, services, temporary work agencies, healthcare, education, public sector, and others. 
Table 3: DI inflow model estimates for small employers (balanced panel; 2008-2011). Clustered standard errors in parentheses

\begin{tabular}{|c|c|c|c|c|c|c|}
\hline & (i) & (ii) & (iii) & (iv) & (v) & (vi) \\
\hline Dependent variable & $\begin{array}{l}\text { DI inflow } \\
\text { rate }\end{array}$ & $\begin{array}{l}\text { DI inflow } \\
\text { rate }\end{array}$ & $\begin{array}{c}\Delta \mathrm{DI} \\
\text { enrolment }\end{array}$ & $\begin{array}{l}\text { DI inflow } \\
\text { rate }\end{array}$ & $\begin{array}{l}\text { DI inflow } \\
\text { rate }\end{array}$ & $\begin{array}{l}\text { DI inflow } \\
\text { rate }\end{array}$ \\
\hline Estimation method & OLS & $\begin{array}{c}\text { Fractional } \\
\text { Logit }\end{array}$ & OLS & FE & FE & FD \\
\hline Private insurance & $\begin{array}{c}-0.051 \\
(0.0069) * * *\end{array}$ & $\begin{array}{c}-0.051 \\
(0.012)^{* * *}\end{array}$ & $\begin{array}{c}-0.055 \\
(0.0082)^{* * *}\end{array}$ & $\begin{array}{c}-0.052 \\
(0.010)^{* * *}\end{array}$ & & \\
\hline Private insurance, $\mathrm{t}-1$ & & & & & $\begin{array}{c}0.024 \\
(0.017)\end{array}$ & $\begin{array}{c}0.026 \\
(0.016)\end{array}$ \\
\hline Year dummies & $\mathrm{X}$ & $\mathrm{X}$ & $\mathrm{X}$ & $\mathrm{X}$ & $\mathrm{X}$ & $\mathrm{X}$ \\
\hline Employer size dummies ${ }^{a}$ & $\mathrm{X}$ & $\mathrm{X}$ & $\mathrm{X}$ & $\mathrm{X}$ & $\mathrm{X}$ & $\mathrm{X}$ \\
\hline Worker composition controls ${ }^{b}$ & $\mathrm{X}$ & $\mathrm{X}$ & $\mathrm{X}$ & $X$ & $\mathrm{X}$ & $\mathrm{X}$ \\
\hline Sector dummies ${ }^{c}$ & $X$ & $\mathrm{X}$ & $X$ & & & \\
\hline Fraction variance FE & & & & 0.178 & 0.210 & \\
\hline R-squared & 0.0011 & & 0.0021 & & & 0.0004 \\
\hline \# Observations & 599,871 & 599,871 & 482,464 & 599,871 & 482,464 & 412,708 \\
\hline
\end{tabular}

$*, * *$, and $* * *$ denote significance of the parameter estimate at $10 \%, 5 \%$, and $1 \%$, respectively.

${ }^{a}$ We estimate the effect of employer size as a step function with the following intervals: 0-4, 5-9, 10-14, 15-19, and 20-24 insured workers.

${ }^{\mathrm{b}}$ Worker composition controls include the share of female workers, as well as the shares of the following age categories: $<35,35-44,45-54$, and $>55$ or older.

${ }^{c}$ Sector dummies are used for agriculture, construction, the industrial sector, trade, transportation, services, temporary work agencies, healthcare, education, public sector, and others. 
Table 4: DI inflow model estimates for large employers (balanced panel, 2008-2011). Clustered standard errors in parentheses.

\begin{tabular}{|c|c|c|c|c|c|c|}
\hline & (i) & (ii) & (iii) & (iv) & (v) & (vi) \\
\hline Dependent variable & $\begin{array}{l}\text { DI inflow } \\
\text { rate }\end{array}$ & $\begin{array}{l}\text { DI inflow } \\
\text { rate }\end{array}$ & $\begin{array}{c}\Delta \mathrm{DI} \\
\text { enrolment }\end{array}$ & $\begin{array}{l}\text { DI inflow } \\
\text { rate }\end{array}$ & $\begin{array}{l}\text { DI inflow } \\
\text { rate }\end{array}$ & $\begin{array}{l}\text { DI inflow } \\
\text { rate }\end{array}$ \\
\hline Estimation method & OLS & $\begin{array}{l}\text { Fractional } \\
\text { Logit }\end{array}$ & OLS & FE & FE & FD \\
\hline Private insurance & $\begin{array}{c}-0.025 \\
(0.0049) * * *\end{array}$ & $\begin{array}{l}-0.027 \\
(0.036)\end{array}$ & $\begin{array}{c}-0.019 \\
(0.0056)^{* * *}\end{array}$ & $\begin{array}{c}-0.030 \\
(0.0082)^{* * *}\end{array}$ & & \\
\hline Private insurance, $\mathrm{t}-1$ & & & & & $\begin{array}{c}0.024 \\
(0.011)^{* *}\end{array}$ & $\begin{array}{c}0.021 \\
(0.013)^{*}\end{array}$ \\
\hline Year dummies & $X$ & $\mathrm{X}$ & $\mathrm{X}$ & $\mathrm{X}$ & $\mathrm{X}$ & $\mathrm{X}$ \\
\hline Employer size dummies ${ }^{a}$ & $X$ & $\mathrm{X}$ & $\mathrm{X}$ & $\mathrm{X}$ & $\mathrm{X}$ & $\mathrm{X}$ \\
\hline Worker composition controls ${ }^{b}$ & $\mathrm{X}$ & $\mathrm{X}$ & $X$ & $\mathrm{X}$ & $\mathrm{X}$ & $\mathrm{X}$ \\
\hline Sector dummies ${ }^{c}$ & $\mathrm{X}$ & $\mathrm{X}$ & $X$ & & & \\
\hline Fraction variance FE & & & & 0.297 & 0.316 & \\
\hline R-squared & 0.0143 & & 0.0156 & & & 0.0006 \\
\hline \# Observations & 86,946 & 86,946 & 69,958 & 86,946 & 69,958 & 52,377 \\
\hline
\end{tabular}

$*, * *$, and $* * *$ denote significance of the parameter estimate at $10 \%, 5 \%$, and $1 \%$, respectively.

${ }^{a}$ We estimate the effect of employer size as a step function with the following intervals: $25-34,35-49,50-74,75-99$, 100-250, and $>250$ insured workers.

${ }^{\mathrm{b}}$ Worker composition controls include the share of female workers, as well as the shares of the following age categories: $<35,35-44,45-54$, and $>55$ or older.

${ }^{c}$ Sector dummies are used for agriculture, construction, the industrial sector, trade, transportation, services, temporary work agencies, healthcare, education, public sector, and others. 
Table 5: Heterogeneity in effect estimates of private insurance on DI inflow rates. Clustered standard errors in parentheses.

\begin{tabular}{|c|c|c|c|c|}
\hline \multirow[b]{2}{*}{ Full sample } & \multicolumn{2}{|c|}{$\begin{array}{l}\text { Pooled OLS estimates - } \\
\text { Equation [3] }\end{array}$} & \multicolumn{2}{|c|}{$\begin{array}{c}\text { FE estimates, with } \\
\text { lagged values of private } \\
\text { insurance - Equation [6] }\end{array}$} \\
\hline & -0.048 & $(0.0062)^{* * *}$ & 0.023 & $(0.014)^{*}$ \\
\hline \multicolumn{5}{|l|}{ Size effects: \# insured workers } \\
\hline$<10$ & -0.043 & $(0.0091) * * *$ & 0.017 & $(0.021)$ \\
\hline $10-24$ & -0.062 & $(0.0088)^{* * *}$ & 0.050 & $(0.026)^{* *}$ \\
\hline $25-49$ & -0.037 & $(0.011)^{* * *}$ & -0.001 & $(0.024)$ \\
\hline $50-99$ & -0.037 & $(0.011)^{* * *}$ & 0.041 & $(0.022)^{*}$ \\
\hline $100-149$ & -0.022 & $(0.016)$ & 0.013 & $(0.033)$ \\
\hline$\geq 150$ & 0.011 & $(0.010)$ & 0.010 & $(0.014)$ \\
\hline \multicolumn{5}{|l|}{ Sectors } \\
\hline Industrial sector, building & -0.064 & $(0.012)^{* * *}$ & -0.036 & $(0.022)$ \\
\hline Services, transport, trade & -0.034 & $(0.0086)^{* * *}$ & 0.031 & $(0.021)$ \\
\hline Care, education, public sector & -0.051 & $(0.019)^{* * *}$ & 0.094 & $(0.052)^{*}$ \\
\hline \multicolumn{5}{|c|}{ Interaction effects: small employers } \\
\hline Private insurance: constant & 0.016 & $(0.022)$ & -0.007 & $(0.045)$ \\
\hline $\begin{array}{l}\text { Private insurance * average DI } \\
\text { inflow in sector (two-digit) }\end{array}$ & -0.379 & $(0.131)^{* * *}$ & 0.180 & $(0.277)$ \\
\hline \multicolumn{5}{|c|}{ Interaction effects: large employers } \\
\hline Private insurance: constant & 0.001 & $(0.016)$ & -0.054 & $(0.038)$ \\
\hline $\begin{array}{l}\text { Private insurance * average DI } \\
\text { inflow in sector (two-digit) }\end{array}$ & -0.174 & $(0.101)^{*}$ & 0.454 & $(0.236)^{*}$ \\
\hline
\end{tabular}


Table 6: Employer fixed-effect estimates of the effect of experience rating differentials (2007-2011). Clustered standard errors in parentheses.

\begin{tabular}{lccc} 
& \multicolumn{2}{c}{ Dependent variable } \\
& $\begin{array}{c}\text { Insured } \\
\text { workers per } \\
\text { employer (fte) }\end{array}$ & Private insurance \\
\hline 'Large' employer & 5.33 & 0.020 & 0.019 \\
(with high level of experience rating) & $(0.070)^{* * *}$ & $(0.0049)^{* * *}$ & $(0.0050)^{* * *}$ \\
Employer size polynomials (\#=5) & & & $\mathrm{X}$ \\
Year dummies & $\mathrm{X}$ & $\mathrm{X}$ & $\mathrm{X}$ \\
Worker composition controls ${ }^{\mathrm{a}}$ & $\mathrm{X}$ & $\mathrm{X}$ & $\mathrm{X}$ \\
Sector dummies & $\mathrm{X}$ & $\mathrm{X}$ & $\mathrm{X}$ \\
Fraction variance due to $\mathrm{FE}$ & 0.998 & 0.851 & 0.851 \\
R-squared (overall) & 0.046 & 0.0082 & 0.0063 \\
\# Observations & 414,047 & 414,047 & 414,047 \\
\hline
\end{tabular}

*,**, and *** denote significance of the parameter estimate at $10 \%, 5 \%$, and $1 \%$, respectively.

${ }^{a}$ Worker composition controls include the share of female workers, as well as the shares of the following age categories: $<35,35-44,45-54$, and $>55$ or older. 
Figure 1: Annual DI award and enrolment rate per insured worker in the Netherlands, 1968-2012 (Koning and Lindeboom, 2015)

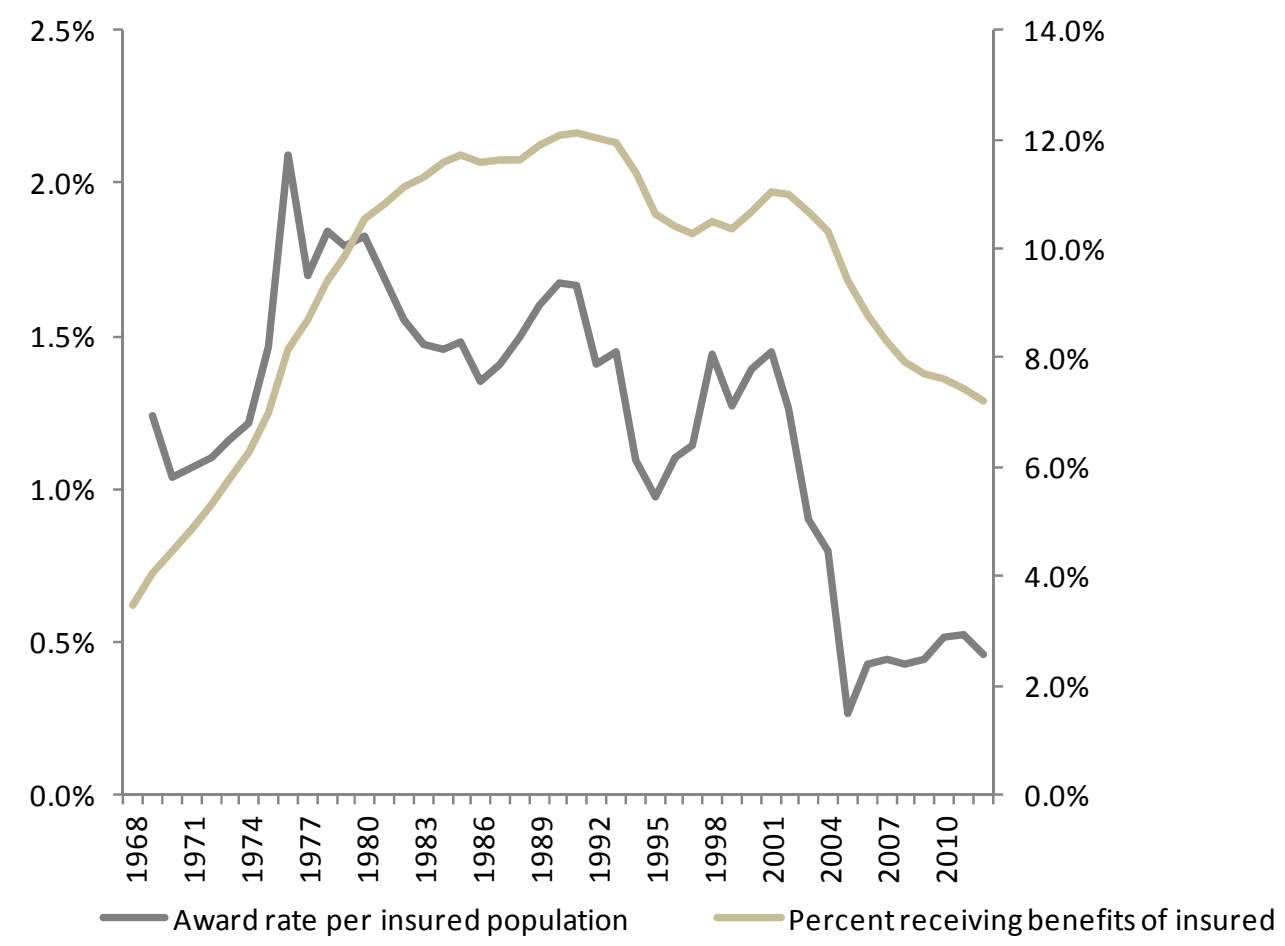


Figure 2: The relation between the degree of experience rating and employer size*

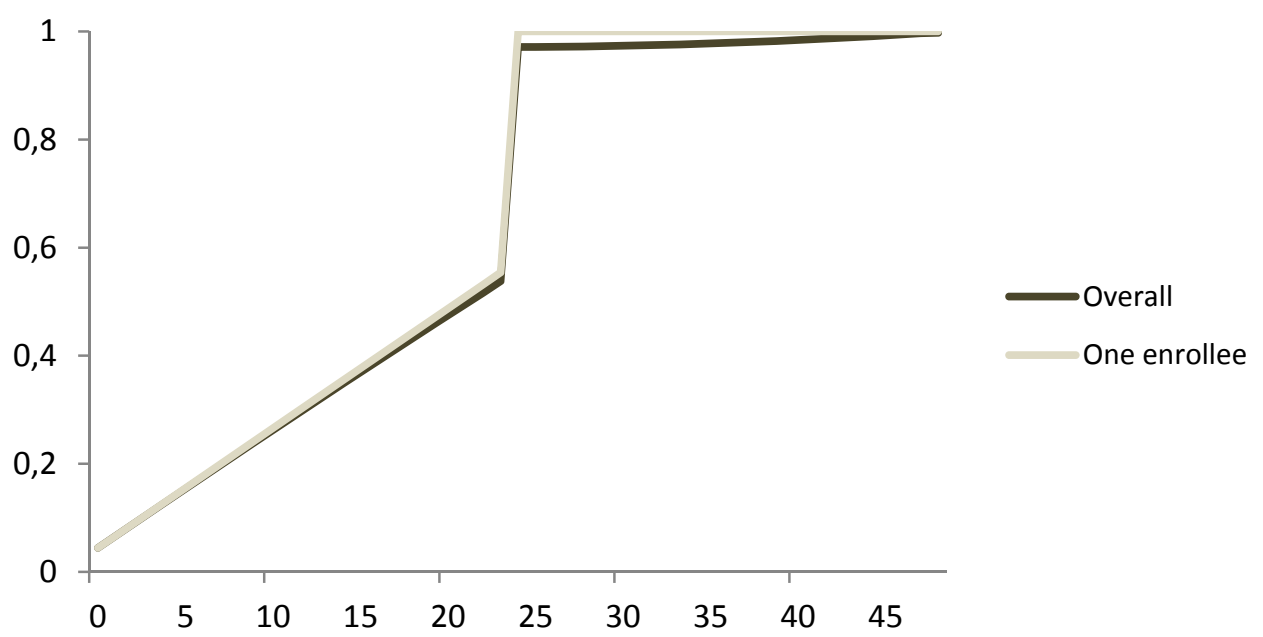

*Note: in this figure, we assume all worker to have a wage sum that equals the average wage sum that is used in the experience rating system. In this context, we evaluate the degree of experience rating - i.e., the share of DI costs - that applies to employers with one worker that enters into DI. 
Figure 3: Share of employers with private insurers per size category (balanced panel; 2007 and 2011)

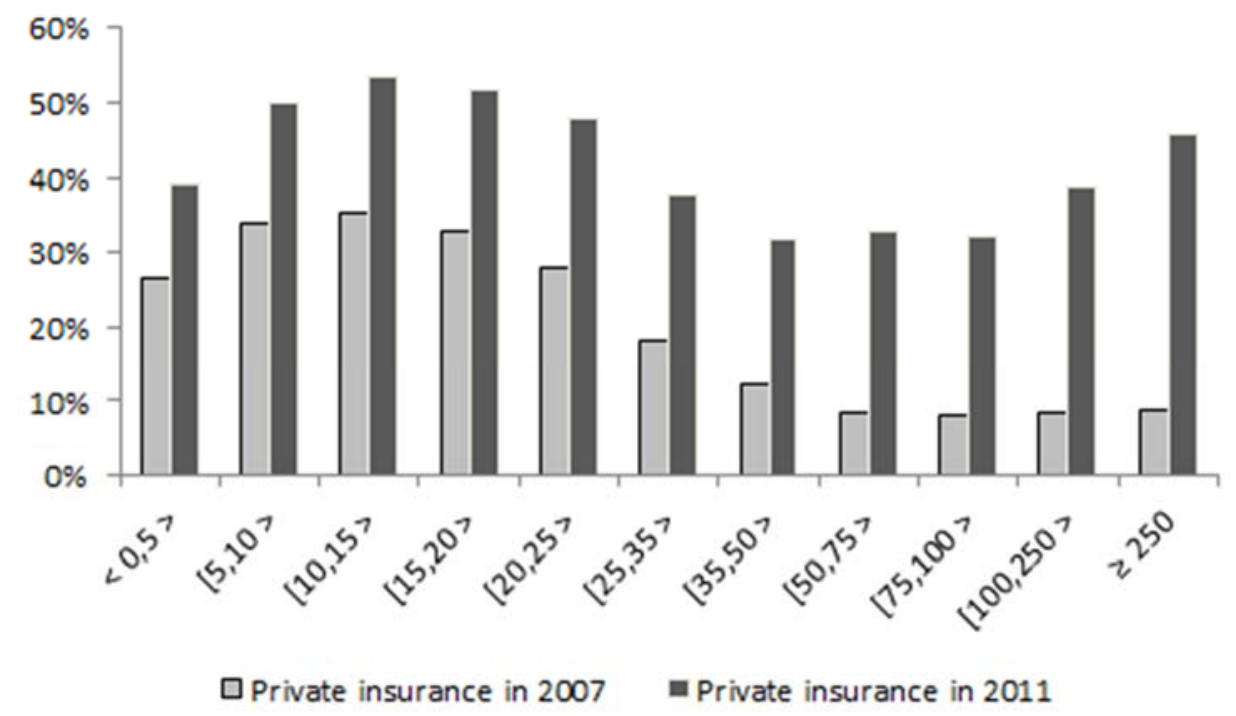

Figure 4: Scatterplot of sectoral averages of annual DI inflow rates and sectoral share of employers with private insurance (2007-2011).

Point observations weighted by number of employers per sector

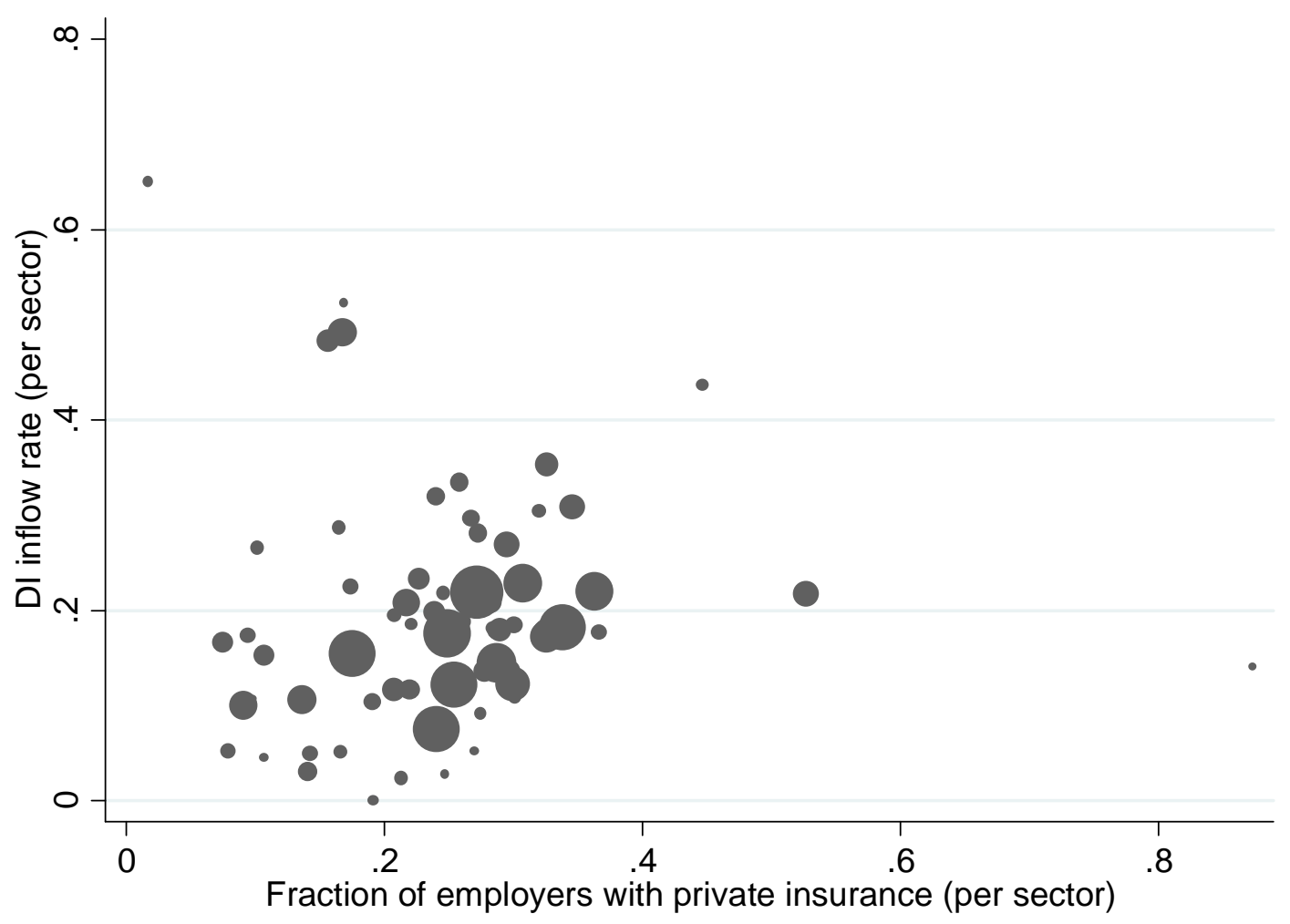


Figure 5: Relative differences in DI inflow and DI enrolment of employers with private versus public insurance (as a percentage of DI enrolment rate with public insurance). Small employers (upper panel) and large employers (lower panel)
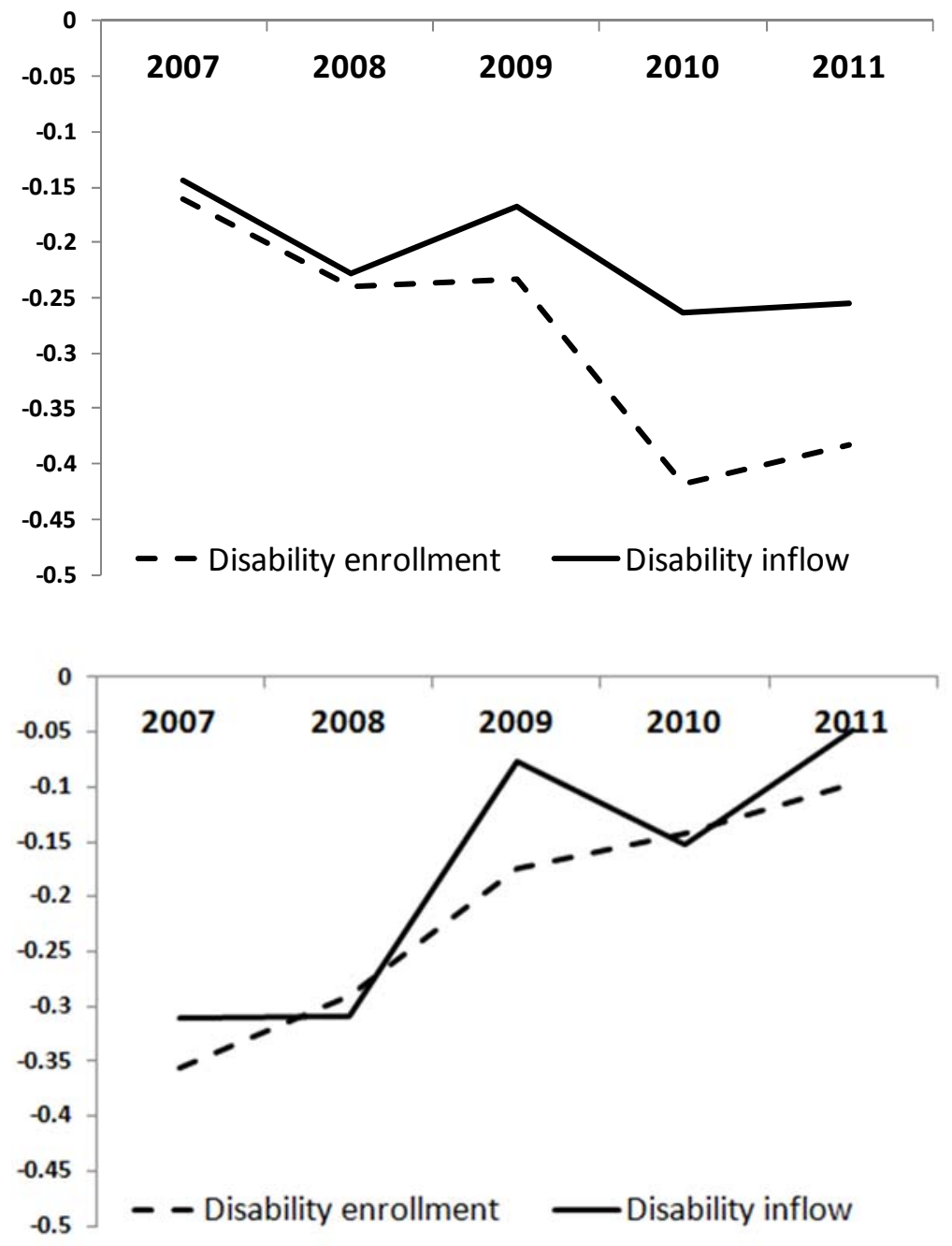